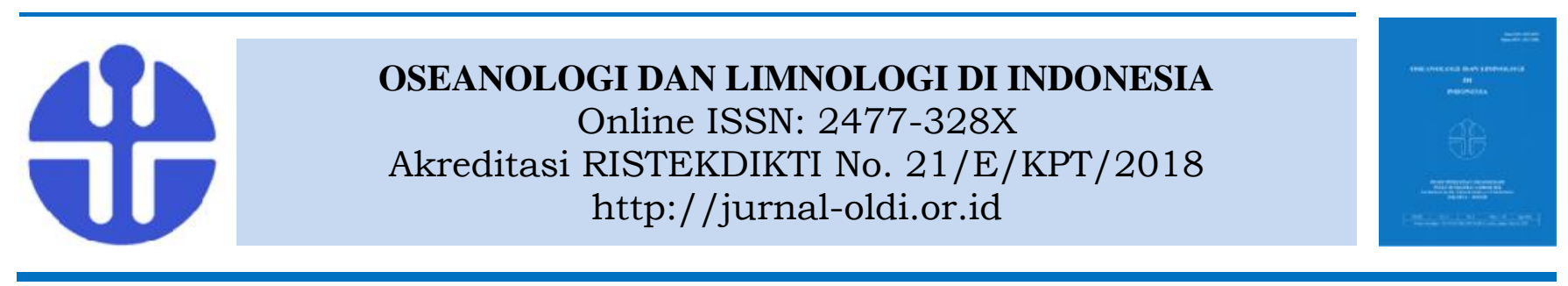

\title{
Pemanfaatan Citra Satelit Penginderaan Jauh dan Sistem Informasi Geografi Untuk Analisis Nilai Ekonomi Ekosistem Pesisir \\ Studi kasus: Desa Teluk Limau, Kecamatan Jebus, Kabupaten Bangka Barat, Provinsi Bangka Belitung
}

\author{
Bayu Prayudha $^{1^{*}}$, Muhammad Hafizt ${ }^{1}$, dan Indra Bayu Vimono ${ }^{1}$ \\ ${ }^{1}$ Pusat Penelitian Oseanografi LIPI \\ Jl. Pasir Putih I, Ancol Timur, Jakarta 14430 \\ *Email: byu30des@gmail.com
}

Submitted 17 April 2018. Reviewed 11 July 2019. Accepted 9 March 2020.

DOI: 10.14203/oldi.2020.v5i1.203

\begin{abstract}
Abstrak
Terumbu karang, padang lamun, dan mangrove merupakan ekosistem penting sebagai sumber nutrisi serta tempat hidup bagi banyak biota laut. Indonesia dengan konsentrasi penduduk berada di wilayah pesisir, sangat menggantungkan kehidupannya kepada ketiga ekosistem tersebut. Meskipun demikian, informasi sebaran ekosistem tersebut masih kurang karena lokasinya relatif sulit dijangkau. Penginderaan jauh dapat menjawab kebutuhan tersebut karena dapat menjangkau wilayah yang luas serta sulit dijangkau. Informasi yang dihasilkan dari data penginderaan jauh dapat memberikan gambaran secara spasial mengenai wilayah yang dikaji, sehingga memudahkan penentu kebijakan dalam mengelola wilayahnya. Salah satu pemanfaatan informasi tersebut adalah penilaian ekonomi ekosistem pesisir dengan menggunakan parameter spasial berupa luasan habitat serta panjang garis pantai yang terlindung oleh ekosistem sebagai faktor pengali, dimana informasi tersebut dapat diperoleh secara cepat, mudah, dan relatif akurat menggunakan penginderaan jauh. Tujuan dari penelitian ini adalah memanfaatkan data penginderan jauh untuk estimasi nilai potensi ekonomi ekosistem pesisir khususnya terumbu karang dan mangrove. Metode yang digunakan pada penelitian ini yaitu pengolahan data citra satelit LANDSAT 8 OLI sebagai bahan utama dikombinasikan dengan Sistem Informasi Geografi (SIG) untuk menghasilkan informasi spasial habitat (panjang dan luas) dan pendekatan barang pengganti (surrogate market prices) untuk penilaian ekonominya. Lokasi penelitian dilakukan di Desa Teluk Limau, Kecamatan Jebus, Kabupaten Bangka Barat, Provinsi Babel. Hasil penelitian berupa peta lingkungan pesisir yang terdiri dari empat kelas habitat, yaitu karang, hamparan makroalga, substrat terbuka, serta mangrove. Berdasarkan informasi spasial yang dihasilkan dari peta tersebut, didapatkan nilai ekonomi ekosistem pesisir yaitu 141,4 milyar rupiah untuk terumbu karang dan 31,1 milyar rupiah untuk ekosistem mangrove.
\end{abstract}

Kata kunci: Penginderaan jauh, SIG, nilai ekonomi, ekosistem pesisir, pemetaan habitat.

\begin{abstract}
The Application of Remote Sensing and Geographical Information System (GIS) for Economic Value Analysis of Coastal Ecosystem. Case Study: Teluk Limau Vilage, Jebus District, West Bangka Regency, Bangka Belitung Province. Coral reefs, seagrass, and mangroves are important ecosystems as the source of nutrients and as the habitat provider for marine biotas. Sustainability of those ecosystems is
\end{abstract}


important for Indonesians while many of them lived in the coastal region. However, information on those ecosystems is still lacked, because most of the area is difficult to reach. Remote sensing would provide a possibility to address the problem. Remote sensing can present a spatial description of a certain area, so it gives a better understanding for the policy maker to manage their area. One of the utilization of this information is to calculate the economic value of coastal ecosystems. The valuation would involve spatial parameters of both the extent of habitat and the length of ecosystem-protected coastline as a multiplier factor. Those parameters can be obtained quickly, easily and accurately using remote sensing. The purpose of this research is to apply remote sensing data for the economic valuation of coastal ecosystems. The method used was the combination of image processing of LANDSAT-8 satellite data and GIS to calculate spatial parameters of habitat, and surrogate market prices approach to assess the economic value of the ecosystems. The research was conducted in Teluk Limau Village, Jebus District, West Bangka Regency, Babel Province. This research has mapped four habitat classes of the coastal ecosystem including coral, macroalgae bed, bare substrate, and mangrove. Based on the spatial information of the map, the economic value of coral reef and mangrove was 141.4 billion rupiahs and 31.1 billion rupiahs respectively.

Keywords: Remote sensing, GIS, economic value, coastal ecosystem, habitat mapping.

\section{Pendahuluan}

Penginderaan jauh merupakan salah satu teknologi yang perkembangannya cukup pesat saat ini. Keunggulan penginderaan jauh salah satunya adalah mampu merekam wilayah yang luas serta sulit dijangkau, sehingga dapat memberikan gambaran sinoptik dan holistik suatu wilayah (Lillesand et al., 2004). Gambaran menyeluruh tersebut sangat dibutuhkan bagi penentu kebijakan dalam mengelola wilayahnya, sebagai contoh wilayah pesisir yang memiliki beberapa ekosistem penting. Terumbu karang, padang lamun, dan mangrove merupakan ekosistem penting didalam pengelolaan laut dan pesisir (Dahuri et al., 1996). Ketiga ekosistem tersebut secara ekologis merupakan sumber nutrisi serta tempat hidup bagi banyak biota laut. Undang-Undang Nomor 27 Tahun 2007 mengenai pengelolaan wilayah pesisir dan pulau-pulau kecil mengatur mengenai pemanfaatan yang tidak merusak serta perlindungan terhadap ketiga ekosistem Selain penting secara ekologis, ketiga ekosistem tersebut juga menunjang kehidupan masyarakat pesisir yang jumlahnya sangat besar di Indonesia. Berdasarkan data KKP Tahun 2015 (Pusat Data Statistik \& Informasi KKP, 2015), 327 kabupaten/kota dari total 514 kabupaten/kota di Indonesia berada diwilayah pesisir. Hal tersebut menunjukkan bahwa masyarakat di Indonesia sangat tergantung pada wilayah pesisir. Pembangunan yang dilakukan diwilayah pesisir perlu memperhatikan keberadaan ketiga ekosistem penting tersebut, agar keberlanjutan pemanfaatannya tetap terjaga. Meskipun demikian, data dan informasi mengenai ekosistem pesisir di Indonesia dirasakan masih kurang. Hal tersebut disebabkan karena wilayah Indonesia yang luas serta lokasinya banyak yang masih sulit untuk dijangkau. Keunggulan penginderaan jauh yang telah disebutkan di atas, dapat dimanfaatkan untuk pemenuhan kebutuhan informasi tersebut. Informasi keruangan yang dihasilkan dari data penginderaan jauh dapat memberikan pengetahuan mengenai karakteristik wilayah pesisir serta persebaran ekosistemnya. Lebih jauh, informasi tersebut dapat dikuantifikasikan untuk mendapatkan informasi baru yang bermanfaat bagi penggunanya. Salah satu contoh pemanfaatan informasi tersebut adalah untuk mengkuantifikasikan manfaat ekonomi dari ekosistem pesisir. Penilaian ekonomi ekosistem pesisir dapat digunakan untuk memberikan wawasan dan kesadaran kepada masyarakat mengenai pentingnya menjaga kelestarian ekosistem pesisir.

Dalam melakukan proses penilaian ekonomi tersebut, dibutuhkan informasi yang bersifat spasial untuk mengkuantifikasikan suatu ukuran atau dimensi ruang, seperti posisi, jarak, panjang, atau luasan. Informasi tersebut dapat dianalisis dari data spasial, sebagai contoh untuk wilayah pesisir melalui peta persebaran habitat pada suatu ekosistem. Pemanfaatan teknologi penginderaan jauh untuk menyediakan informasi mengenai ekosistem pesisir seperti habitat bentik dan mangrove hingga saat ini terus berkembang (Hafizt \& Danoedoro, 2015; Hafizt et al., 2017a, 2017b; Kamal et al., 2015; Long \& Skewes, 1996; Suyarso et al., 2011) seiring ketersediaan data resolusi tinggi yang mudah diperoleh (ESA, 2015; LSDS-1574 V1, 2015). Sebagai contoh, akurasi yang dihasilkan dari penggunaan data penginderaan jauh yang mudah didapat yaitu LANDSAT ETM+ dapat mencapai 60 hingga 
75\% (Goodman et al., 2013). Meskipun pemanfaatan data penginderaan jauh untuk analisis spasial dalam penilaian ekonomi tersebut cukup menjanjikan, pendekatan tersebut hanya dapat memberikan gambaran distribusi habitat pada suatu ekosistem secara statis, sehingga nilai ekonomi yang dihasilkan juga bersifat statis (Costanza et al., 1997; Nemec \& RaudseppHearne, 2012). Pendekatan dinamis atau multitemporal akan lebih baik, karena dapat menyajikan gambaran pada masa lampau dan yang akan datang. Hal tersebut sangat bermanfaat bagi penentu kebijakan untuk melihat dampak perubahan ekosistem dan pengaruhnya terhadap nilai ekonomi yang dihasilkan dari kebijakan dalam pengelolaan wilayah atau ekosistem tersebut (Nemec \& Raudsepp-Hearne, 2012). Beberapa kajian mengenai penilaian ekonomi ekosistem pesisir sudah dilakukan di Indonesia, diantaranya adalah Nahib (2011), Maharmingnastiti et al. (2015), Hermalena (2016), Mira et al. (2017). Meskipun demikian, dalam prosesnya belum sepenuhnya berbasis pada data spasial karena hanya menggunakan data sekunder berupa informasi luasan sehingga tidak tertelusur keakuratan datanya dalam menyajikan aspek spasial. Tingkat akurasi data yang dihasilkan dari penginderaan jauh sangat dibutuhkan untuk mengontrol kelayakan informasi yang dihasilkan, terutama terkait dengan informasi spasial.

Nilai ekonomi pada suatu ekosistem terhadap tiap objek yang bernilai ekonomis dapat diketahui menggunakan persamaan-persamaan tertentu (Hermalena, 2016; Maharmingnastiti et al., 2015; Suparmoko et al., 2003). Beberapa persamaan dalam Suparmoko et al. (2003) menggunakan parameter luasan area dari karang dan mangrove yang dapat diperoleh secara cepat, mudah dan relatif akurat menggunakan teknologi penginderaan jauh yang dikombinasikan dengan SIG (Green et al., 2000).

Tujuan dari penelitian ini adalah memberikan contoh penilaian ekonomi ekosistem pesisir khususnya terumbu karang dan mangrove dengan memanfaatkan data citra satelit serta Sistem Informasi Geografi (SIG) sebagai perangkat analisisnya. Lokasi penelitian dilakukan di Desa Teluk Limau, Kecamatan Jebus, Kabupaten Bangka Barat, Provinsi Babel. Daerah tersebut cukup menarik karena selain memiliki ekosistem pesisir, juga merupakan daerah pertambangan timah yang proses penyuciannya dilakukan pada wilayah tersebut. Penilaian potensi ekonomi ekosistem pesisir menjadi penting di wilayah tersebut karena belum pernah dilakukan, dan dapat dijadikan bahan pertimbangan bagi penentu kebijakan di daerah sebagai pembanding nilai ekonomi yang dihasilkan dari sektor lain, misalnya pertambangan. Lebih jauh, hasil dari kajian ini diharapkan dapat menjadi informasi penting dalam pengelolaan ekosistem pesisir berbasis data yang terus dikembangkan dalam kebijakan One Map Policy (Giyanto et al., 2017).

\section{Metodologi}

Penelitian ini dilakukan dengan mengambil contoh di Desa Teluk Limau, Kecamatan Jebus, Kabupaten Bangka Barat, Provinsi Bangka Belitung (Gambar 1). Dua metode yang digunakan yaitu metode pengolahan citra satelit (image processing) dan metode perhitungan nilai ekonomi. Metode pengolahan citra satelit digunakan untuk menentukan parameter spasial yaitu luas dan panjang terumbu karang dan mangrove yang ada. Selanjutnya, hasil penghitungan citra satelit diaplikasikan untuk mengetahui nilai ekonomi ekosistem terumbu karang, mangrove dan lamun

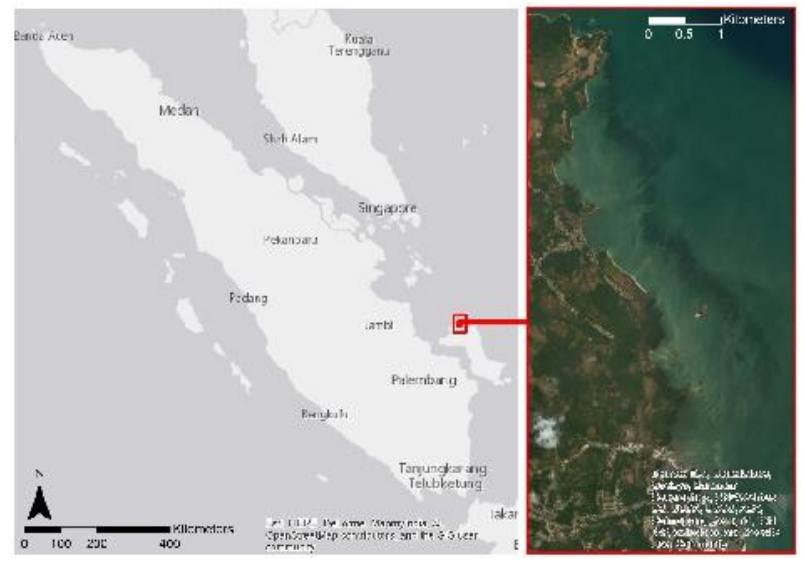

Gambar 1. Lokasi penelitian, Desa Teluk Limau, Kecamatan Jebus, Kabupaten Bangka Barat, Provinsi Bangka Belitung

Figure 1. Research location, Teluk Limau Village, Jebus Subdistrict, Bangka Barat District, Bangka Belitung Province

Metode pengolahan citra terdiri dari koreksi dan klasifikasi citra menggunakan aplikasi image processing serta perhitungan parameter spasial menggunakan aplikasi Sistem Informasi Geografis (SIG). Citra yang digunakan adalah citra LANDSAT 8 OLI periode perekaman 24 September 2013. Citra tersebut memiliki saluran biru yang penting bagi kajian habitat bentik (Goodman et al., 2013; Green et al., 2000; Jensen, 2007) dan resolusi spasial citra sebesar 30 meter 
yang cukup representatif untuk memperoleh luasan terumbu karang dan mangrove. Citra LANDSAT 8 yang digunakan adalah level 1T yang telah terkoreksi Top-of-Atmosphere (TOA) sehingga koreksi lanjutan yang dilakukan adalah koreksi atmosfer dan koreksi kolom air (Prayudha, 2014). Kedua koreksi tersebut meminimalisir kesalahan pada nilai piksel yang terjadi akibat pengaruh atmosfer dan pelemahan kolom air sehingga hasil klasifikasi dan perhitungan luasan lebih akurat, khususnya pada tutupan terumbu karang (Hafizt \& Danoedoro, 2015).

Metode koreksi yang digunakan adalah Dark Object Sutraction (DOS) (Chavez, 1988) untuk koreksi atmosfer dan Depth Invariant Index (DII) (Green et al., 2000) untuk koreksi kolom air. Piksel pada citra hasil koreksi tersebut selanjutnya dikelaskan menggunakan teknik klasifikasi citra tak terbimbing (unsupervised) untuk mengetahui area terumbu karang dan mangrove, kemudian dihitung akurasinya (overall acuracy) berdasarkan uji di lapangan (Danoedoro, 2012). Sampel uji akurasi diperoleh di lapangan menggunakan metode Stop and Go (Prayudha, 2014). Citra hasil klasifikasi selanjutnya diolah menggunakan aplikasi GIS untuk menghitung luas terumbu karang dan mangrove. Aplikasi GIS juga digunakan untuk validasi hasil klasifikasi terutama tutupan mangrove dan diperbaiki menggunakan teknik digitasi layar (on-screen digitizing).

Contoh metode penilaian ekonomi lingkungan pesisir yang digunakan pada penelitian ini mengacu dari persaman yang dibangun oleh Suparmoko et al. (2003) dengan menggunakan pendekatan barang pengganti (surrogate market prices). Perhitungan potensi ekonomi hanya dilakukan pada terumbu karang dan mangrove sesuai fungsi ekologinya sebagai nursery ground dan pelindung garis pantai, serta potensi produktifitas ikan karang dan biota lainnnya, sehingga belum menggambarkan nilai TEV (Total Economic Value) yang merupakan akumulasi dari Total Use Value (TUV) dan Nonuse Value (NUV) (Maharmingnastiti et al., 2015). Contoh penggunaan informasi spasial yang dihasilkan dari data penginderaan jauh dalam penilaian ekonomi dapat dilihat pada Gambar 2 dan Tabel 1. Gambar 2 menunjukkan rincian komponen ekosistem terumbu karang dan mangrove yang dihitung pada penelitian ini. Sedangkan rincian persamaannya dapat dilihat pada Tabel 1 .

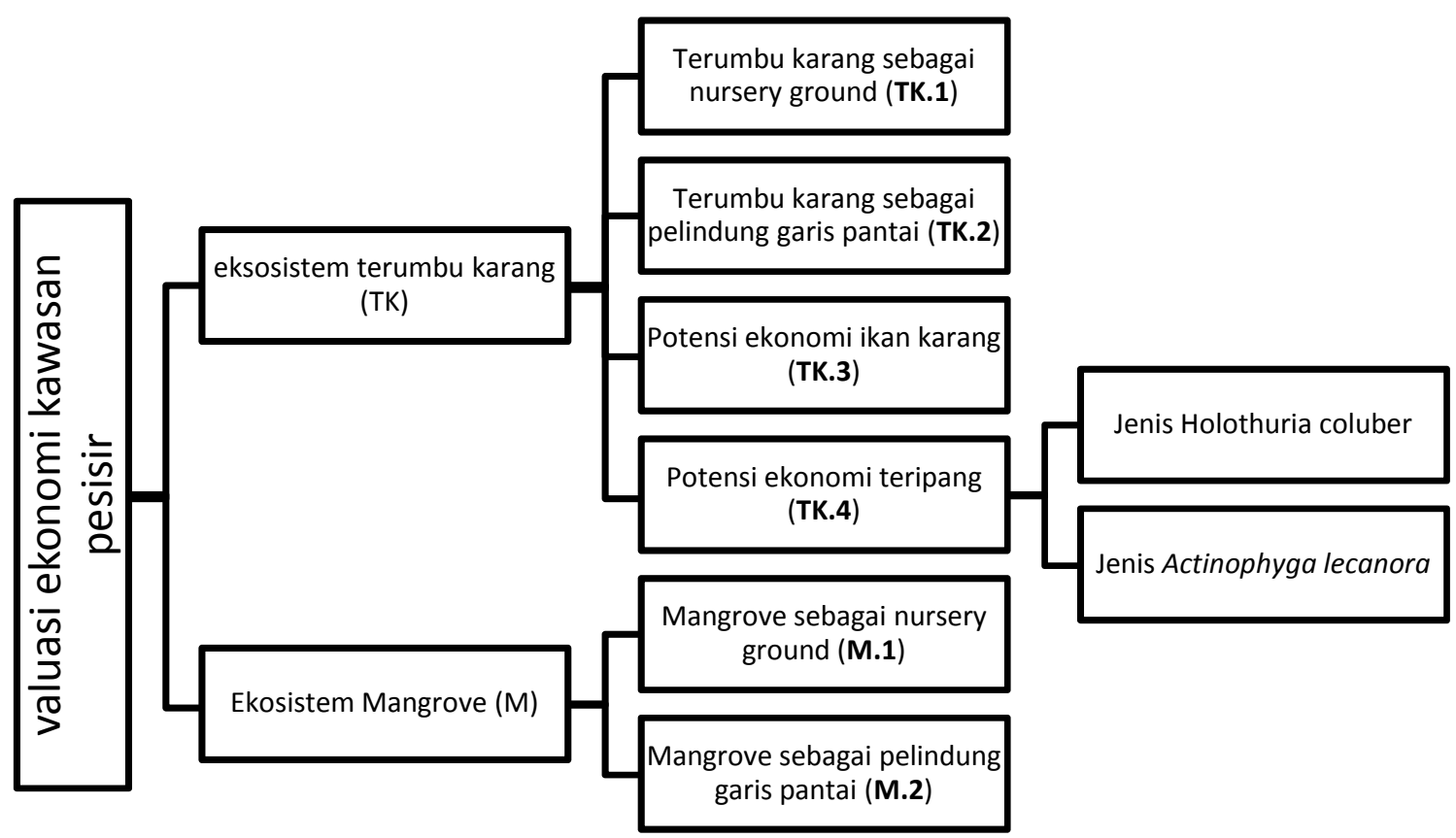

Gambar 2. Diagram potensi ekosistem terumbu karang dan mangrove yang digunakan untuk perhitungan nilai ekonomi kawasan pesisir

Figure 2. Diagram of ecosystem potencies of coral reef and mangrove which are used to calculate economic value of coastal area 
Tabel 1. Persamaan surrogate market prices untuk menghitung beberapa nilai ekonomi di Ekosistem pesisir dan mangrove

Table 1. Surrogate market prices equation for counting several economic value of coral reef and mangrove

\begin{tabular}{|c|c|c|c|}
\hline Code & Parameters & Equations & Notes \\
\hline TK.1 & $\begin{array}{l}\text { The economic value of } \\
\text { coral reefs as a nursery } \\
\text { ground }\end{array}$ & $V_{n}=\beta x L_{t} x U_{n}$ & $\begin{array}{l}\text { The equation used spatial parameter of coral } \\
\text { habitat extent as multiplying factor, where: } \\
\mathrm{Vn}=\text { the economic value of coral reefs as nursery } \\
\text { ground } \\
-B=\text { the coefficient of intact coral habitat extent } \\
\text { based on live coral cover data }(\%) \text { from } \\
\text { survey data of Research Center for } \\
\text { Oceanography - LIPI on } 2013 \text {. } \\
-\mathrm{L}_{\mathrm{t}}=\text { the extent of coral habitat based on satellite } \\
\text { image analysis using GIS. } \\
\text { - Un = the rent unit of coral reef as nursery } \\
\text { ground. (Astuti et al., 2008; Noviyanti \& } \\
\text { Rusdiyanto, 2009) }\end{array}$ \\
\hline TK.2 & $\begin{array}{l}\text { The economic value of } \\
\text { coral reefs as shoreline } \\
\text { protection }\end{array}$ & $V_{p}=P_{t} x T_{t} x B_{t}$ & $\begin{array}{l}\text { The equation is assumed by the construction cost } \\
\text { of shoreline detain wall, where: } \\
-\mathrm{V}_{\mathrm{P}}=\text { the economic value of coral reefs as } \\
\text { shoreline protection } \\
-\mathrm{Pt}=\text { the length of reef-protected shoreline based } \\
\text { on satellite image analysis using GIS. } \\
-\mathrm{Tt}=\text { the height of detain wall }(2,5 \mathrm{~m}) \text { based on } \\
\text { example of reference cost for shoreline } \\
\text { detain wall construction in Permen PUPR } \\
\text { No. } 28 / \mathrm{PRT} / \mathrm{M} / 2016 . \\
-\mathrm{Bt}=\text { the expense cost for detain wall } \\
\text { construction }\left(\mathrm{Rp} / \mathrm{m}^{2}\right) \text { based on example of } \\
\text { reference cost for shoreline detain wall } \\
\text { construction in Permen PUPR No. } \\
28 / \mathrm{PRT} / \mathrm{M} / 2016 \text {. }\end{array}$ \\
\hline
\end{tabular}

TK.3 The economic value of $V_{i k}=K_{i} x L_{t} x H$ reef fish

The equation is assumed by multiplying the average of reef fish density with the extent of reef area, where:

Vik $=$ the economic value of reef fish .

$\mathrm{Ki}=$ the average of reef fish density based on visual census survey data of Research Center for Oceanography - LIPI in 2013.

$\mathrm{Lt}=$ the extent of reef area based on satellite image analysis using GIS.

$\mathrm{H}=$ the market price of reef fish based on field information from the local fisherman (personal communication on October 10, 2013).

TK.4 The economic value of $V_{t r}=K_{r} x L_{t} x H \quad$ The equation is assumed by multiplying the sea cucumber average of sea cucumber density with the extent of reef area, where:

- Vtr $=$ the economic value of sea cucumber

$-\mathrm{Kr}=$ the average of sea cucumber density based on survey data of Research Center for Oceanography - LIPI in 2013.

- $\mathrm{Lt}=$ the extent of reef area based on satellite image analysis using GIS.

$-\mathrm{H}=$ the market price of sea cucumber based on 


\begin{tabular}{|c|c|c|c|}
\hline & & & $\begin{array}{l}\text { field information from the local collectors } \\
\text { and fisherman (personal communication on } \\
\text { October 10, 2013). }\end{array}$ \\
\hline M.1 & $\begin{array}{l}\text { The economic value of } \\
\text { mangrove as nursery } \\
\text { ground }\end{array}$ & $V_{n}=L_{m} x U_{n}$ & $\begin{array}{l}\text { The equation used spatial parameter of mangrove } \\
\text { extent as multiplying factor, where: } \\
\text { - } \mathrm{Vn}=\text { the economic value of mangrove as } \\
\text { nursery ground. } \\
\text { - } \mathrm{Lm}=\text { the extent of mangrove area based on } \\
\text { satellite image analysis using GIS. } \\
\text { - Un = the rent unit of mangrove as nursery } \\
\text { ground (Astuti et al., 2008; Noviyanti \& } \\
\text { Rusdiyanto, 2009). }\end{array}$ \\
\hline M.2 & $\begin{array}{l}\text { The econominc value of } \\
\text { mangrove as shoreline } \\
\text { protection }\end{array}$ & $V_{p}=P_{m} x T_{t} x B_{t}$ & $\begin{array}{l}\text { The equation is assumed by the construction cost } \\
\text { of shoreline detain wall, where: } \\
-\mathrm{V}_{\mathrm{P}}=\text { the econominc value of mangrove as } \\
\text { shoreline protection } \\
-\mathrm{Pm}=\text { the length of mangrove-protected } \\
\text { shoreline based on satellite image analysis } \\
\text { using GIS. } \\
-\mathrm{Tt}=\text { the height of detain wall }(2,5 \mathrm{~m}) \text { based on } \\
\text { example of reference cost for shoreline } \\
\text { detain wall construction in Permen PUPR } \\
\text { No. } 28 / \mathrm{PRT} / \mathrm{M} / 2016 \text {. } \\
\text { - } \mathrm{Bt} \text { the expense cost for detain wall } \\
\text { construction }\left(\mathrm{Rp} / \mathrm{m}^{2}\right) \text { based on example of } \\
\text { reference cost for shoreline detain wall } \\
\text { construction in Permen PUPR No. } \\
\text { 28/PRT/M/2016. }\end{array}$ \\
\hline
\end{tabular}

Data persentase tutupan karang hidup, kelimpahan ikan, dan teripang didapatkan dari data sekunder laporan penelitian Pusat Penelitian Oseanografi LIPI Tahun 2013. Berdasarkan laporan tersebut, data diambil dengan menggunakan menggunakan metode line intercept transect (LIT) (Hill \& Wilkinson, 2004) untuk mengukur persentase tutupan karang hidup serta sensus visual untuk mengetahui kelimpahan ikan karang dan metode benthos belt transect untuk kelimpahan teripang secara insitu melalui penyelaman SCUBA (Giyanto et al., 2014). Nilai pengganti untuk nursery ground berdasarkan pada informasi biaya yang dibutuhkan untuk pembuatan tambak, sedangkan untuk pelindung garis pantai berdasarkan pada biaya yang dibutuhkan untuk pembuatan bangunan pelindung pantai (Tabel 1). Harga ikan dan teripang dipasaran juga didapatkan berdasarkan hasil penelusuran informasi dari nelayan di lapangan.

\section{Hasil}

\section{Analisis Citra Untuk Pemetaan Ekosistem Pesisir}

Sebaran habitat bentik dipetakan menggunakan data citra satelit Landsat 8 path/row 124/061 perekaman 24 September 2013. Citra yang digunakan merupakan citra Landsat 8 level 1T, artinya citra tersebut sudah dikoreksi geometrinya dengan memasukkan posisi atau koordinat geografis yang mempertimbangkan juga pergeseran yang diakibatkan oleh bentuk relief permukaan bumi. Jika dibandingkan dengan pencatatan koordinat melalui GPS receiver di lapangan, citra yang digunakan sudah memiliki geometri yang baik. Hal tersebut ditunjukkan dengan kesesuaian posisi koordinat antara objek di citra maupun di lapangan. Koreksi dilakukan untuk memperbaiki kualitas visual citra akibat gangguan atmosfer dan kolom air. Efek gangguan atmosfer seperti kabut menyebabkan kualitas citra kurang tajam, sehingga objek yang direkam dipermukaan bumi tidak dapat terlihat jelas. Koreksi yang dilakukan dengan menggunakan metode DOS dapat meningkatkan kualitas visual citra akibat ganguan atmosfer. Sinar matahari 


\section{Oseanologi dan Limnologi di Indonesia 2020 5(1): 33-47}

yang datang ke permukaan bumi untuk kemudian direkam oleh sensor satelit, tidak hanya melewati media atmosfer. Lebih jauh, untuk merekam objek habitat bentik perjalanan sinar juga harus melalui media kolom air. Sinar yang masuk ke dalam kolom air akan semakin melemah sejalan dengan kedalaman perairan hingga akhirnya hilang pada perairan yang dalam. Pada citra perekaman perairan dangkal, warna yang dihasilkan dari variasi kedalaman akibat pelemahan sinar sangat sulit dibedakan dengan warna yang dihasilkan dari variasi tutupan bentik atau dasar perairan (Lyzenga, 1978). Oleh karena itu, perlu dilakukan koreksi kolom air untuk mempertajam kenampakan visual objek dasar perairan pada citra agar variasinya dapat terlihat. Hasil koreksi atmosfer dan kolom air yang dilakukan dapat dilihat pada Gambar 3.
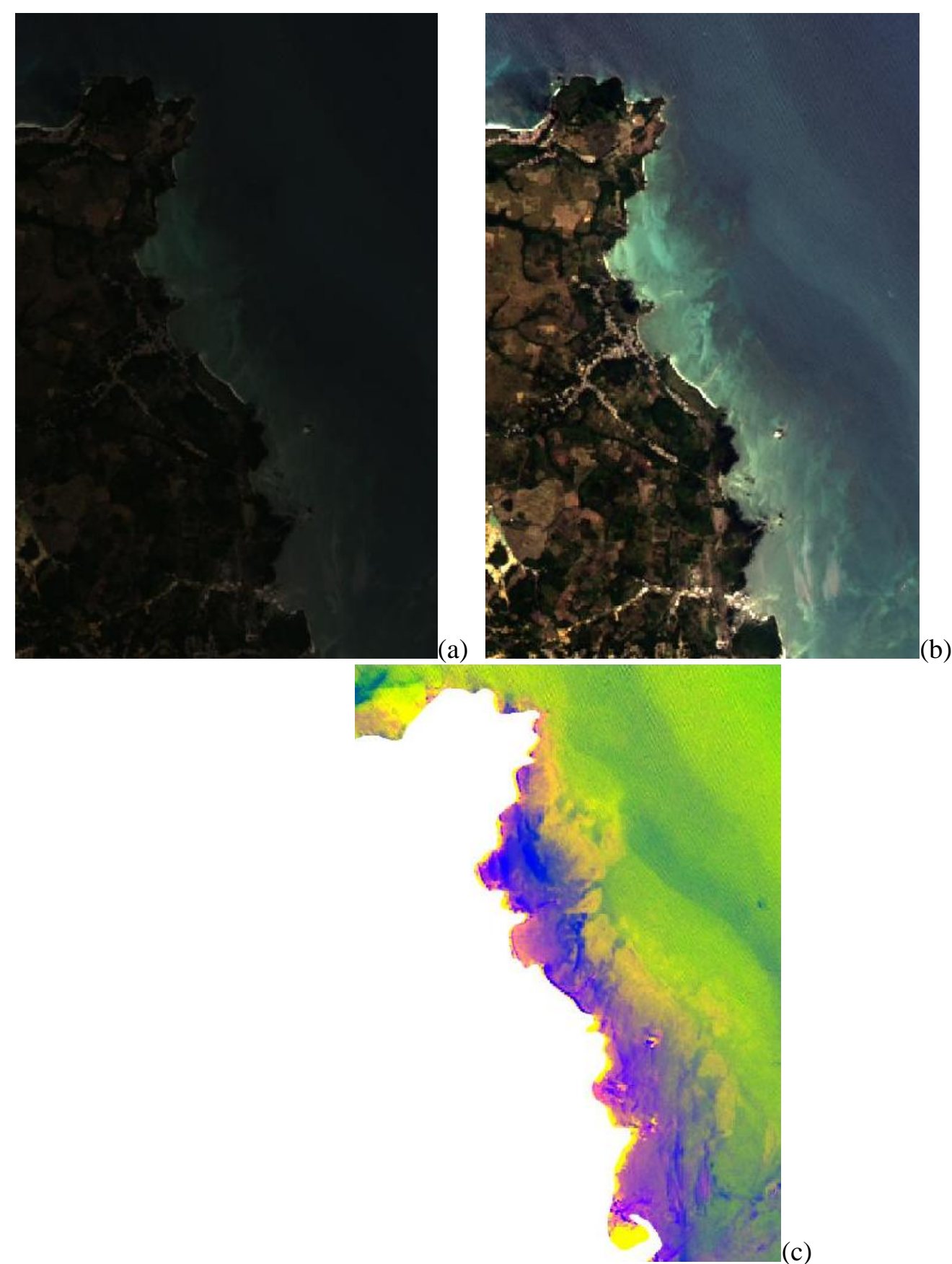

(b)

Gambar 3. Kualitas visual data citra sebelum dan sesudah koreksi (a. sebelum koreksi, b. setelah koreksi atmosfer, c. setelah koreksi kolom air).

Figure 3. The visual quality of image before and after correction (a. origin image, b. after atmospheric correction, c. after water column correction) 
Berdasarkan analisis citra satelit serta dibantu dengan data lapangan (ground truth) dibuat peta sebaran habitat bentik dan mangrove. Habitat bentik yang dapat dipetakan terdiri dari tiga kelas yaitu karang, makroalga, dan substrat terbuka (Gambar 4). Habitat karang pada peta ini merupakan hamparan yang didominasi oleh karang hidup serta karang mati baik yang tertutup alga maupun tidak. Habitat tersebut biasanya ditemui pada ujung wilayah rataan terumbu yang menghadap ke arah laut, mulai dari reef crest, tubir (reef edge) hingga lereng terumbu (slope reef). Makroalga merupakan hamparan yang didominasi oleh tutupan makroalga. Substrat terbuka pada peta merupakan permukaan dasar perairan yang tidak didominasi oleh tutupan biota maupun vegetasi, dapat berupa pasir, batu, maupun lumpur. Lamun tidak dijumpai di wilayah penelitian baik berdasarkan pengamatan dari citra satelit maupun di lapangan.

Akurasi peta habitat bentik yang dihasilkan pada penelitian ini sebesar $71,05 \%$ dihitung berdasarkan 38 titik uji pengamatan lapangan (ground truth). Nilai akurasi tersebut dapat diterima karena melebihi batas minimal nilai akurasi yang dapat diterima (Badan Informasi Geospasial, 2014). Luas total seluruh ekosistem tersebut adalah 901,94 hektar dengan rincan luas dari masing-masing kelas dapat dilihat di peta pada Gambar 4.

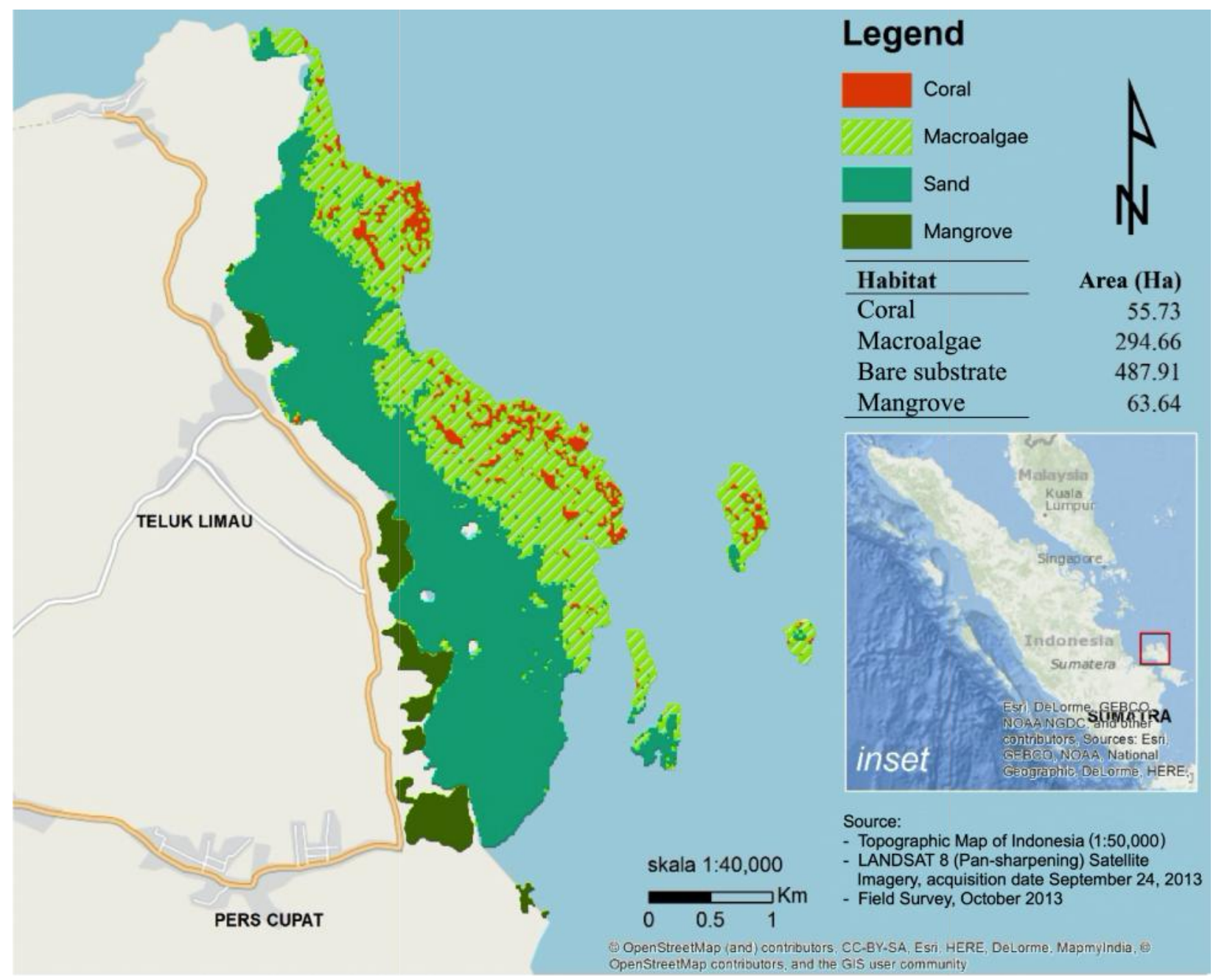

Gambar 4. Peta habitat laut dangkal dan mangrove daerah penelitian

Figure 4. Benthic Habitat and mangrove map of research area

\section{Pemanfaatan Hasil Analisis Citra untuk}

\section{Penghitungan Valuasi Ekonomi}

Definisi operasional dari masing-masing komponen ekosistem pesisir pada penelitian ini adalah: terumbu karang merupakan hamparan wilayah pesisir tersusun dari endapan kapur yang dihasilkan oleh hewan karang pada waktu lampau, serta dihuni oleh atau habitat dari organisme karang, komunitas makroalgae dan hamparan 
pasir; mangrove adalah hamparan wilayah pesisir yang didominasi oleh tanaman mangrove. Hasil penghitungan luasan dan panjang pantai hasil penelitian ini di sajikan dalam Tabel 2. Luas area terumbu karang dan mangrove, serta panjang garis pantai yang terlindung oleh kedua ekosistem tersebut selanjutnya digunakan untuk perhitungan valuasi ekonomi menggunakan persamaan pada Tabel 1. Rincian persamaan dari masing-masing komponen yang dikelompokkan menjadi Terumbu Karang (TK) dan Mangrove (M) dapat dilihat pada Tabel 3.

Tabel 2. Hasil Perhitungan Parameter Spasial Ekosistem Pesisir

Table 2. The Result of Spatial Parameter Calculation of Coastal Ecosystem

\begin{tabular}{llc}
\hline Benthic habitat & $\begin{array}{c}\text { Extent } \\
(\text { ha })\end{array}$ & $\begin{array}{c}\text { Protected } \\
\text { Shoreline } \\
(\mathrm{m})\end{array}$ \\
\hline Reef area: & 838.31 & $10,908.59$ \\
- Coral habitat & 55.73 & \\
- Macroalgae bed & 294.66 & \\
- Bare substrate & 487.91 & \\
\hline Mangrove & 63.64 & $3,245.35$ \\
\hline
\end{tabular}

\section{Valuasi Ekonomi Terumbu Karang}

Berdasarkan laporan penelitian Puslit Oseanografi - LIPI Tahun 2013, diketahui persentase tutupan karang hidup di Bangka Barat adalah sebesar $53,63 \%$. Nilai tersebut digunakan untuk menghitung nilai ekonomi pada persamaan TK.1 (Tabel 3) untuk mengkalikan dengan luas habitat karang dan unit rent nursery ground. Luas habitat karang didapatkan dari peta habitat yang dihasilkan dari citra satelit yaitu 55,73 ha, sedangkan unit rent sebagai nursery ground didasarkan pada Astuti et al. (2008) dan Noviyanti \& Rusdiyanto (2009) untuk biaya pembuatan tambak di Bontang, Kalimantan Timur dan Banten adalah sebesar Rp. 15.000,- $/ \mathrm{m}^{2}$. Jika di konversi kedalam satuan hektar (ha), maka biaya pembuatan tambak per-hektar adalah sebesar Rp 150.000.000,-. Biaya investasi untuk tambak dikeluarkan setiap liima tahun sekali karena sesuai dengan batas umur tambak, sehingga manfaat ekonomi sebagai tempat nursery ground adalah Rp 150.000.000,-/lima tahun $=\operatorname{Rp~30.000.000,-~}$ /ha. Berdasarkan asumsi tersebut maka nilai ekonomi terumbu karang sebagai nursery ground adalah sebesar Rp 896.639.970,-/tahun.

Fungsi terumbu karang sebagai pelindung garis pantai didapatkan melalui persamaan TK.2 (Tabel 3), yaitu dengan mengkalikan panjang garis pantai yang dihitung melalui citra satelit dengan perkiraan harga pembuatan tanggul pantai setinggi 2,5 meter. Berdasarkan pengukuran dari citra satelit, panjang garis pantai yang terlindungi terumbu adalah 10.908,59 meter, sedangkan biaya pembuatan tanggul per-meter persegi berdasarkan pada contoh perhitungan Harga Perkiraan Sementara (HPS) untuk pembuatan tanggul laut di Provinsi Jawa Barat Tahun 2012 yang tertuang di Peraturan Menteri Pekerjaan Umum dan Perumahan Rakyat (Permen PUPR) No. 28/PRT/M/2016 adalah Rp. 3.640.133,-. Dalam penelitian ini dibulatkan menjadi Rp. 3.600.000,untuk mempermudah perhitungan. Nilai ekonomi terumbu karang yang dapat difungsikan sebagai pelindung garis pantai adalah sebesar $\mathrm{Rp}$ 98.177.310.000,-.

Nilai ekonomi perikanan dari terumbu karang dihitung dengan persamaan TK.3 dan TK.4, masing-masing dinilai dari kelimpahan ikan karang dan teripang. Data kelimpahan ikan dan teripang berdasarkan pada laporan penelitian Puslit Oseanografi - LIPI Tahun 2013 seperti terlihat pada Tabel 3 yaitu $2.336 \mathrm{ikan} / \mathrm{ha}$ serta $0,0125 \mathrm{individu} / \mathrm{m}^{2}$ atau $125 \mathrm{individu} / \mathrm{ha}$ teripang jenis Holothuria coluber dan 0,0041 individu $/ \mathrm{m}^{2}$ atau 41 individu/ha untuk jenis teripang Actinophyga lecanora. Nilai kelimpahan tersebut kemudian dikali dengan luas total terumbu yaitu 838,31 ha dan harga pasaran ikan dan teripang per-individu untuk masing jenis didaerah penelitian. Berdasarkan asumsi tersebut, nilai ekonomi ikan karang dan teripang di wilayah penelitian masing-masing adalah $\mathrm{Rp}$ 39.165.843.200,- dan Rp. 3.110.130.100,-.

\section{Valuasi Ekonomi Ekosistem Mangrove}

Penilaian ekonomi mangrove berdasarkan fungsinya sebagai nursery ground (M.1) dan pelindung garis pantai (M.2), menggunakan pendekatan yang hampir sama dengan terumbu karang (TK). Nilai potensi ekonomi mangrove sebagai nursery ground dihitung dengan mengkalikan luas mangrove yaitu 63,34 ha dengan nilai unit rent nursery ground (Tabel 3). Fungsi mangrove sebagai pelindung garis pantai (M.2) dihitung dengan mengkalikan panjang garis pantai yang terlindung oleh mangrove dengan biaya pembuatan tanggul pantai. Panjang garis pantai yang terlindung mangrove dihitung dari citra satelit yaitu 3.245,35 m. Berdasarkan asumsi tersebut, maka masing-masing nilai potensi ekonomi mangrove sebagai nursery ground dan pelindung garis pantai adalah sebesar Rp 1.900.200.000,-/tahun dan Rp 29.208.150.000,--

Perbandingan masing-masing potensi ekonomi hasil perhitungan pada Tabel 3 dapat 
dilihat pada Gambar 5. Nilai ekonomi tertinggi di Desa Teluk Limau adalah terumbu karang sebagai pelindung garis pantai. Hal tersebut disebabkan karena garis pantai yang dilindungi oleh hamparan terumbu cukup panjang serta asumsi biaya pembuatan talud yang cukup besar. Sedangkan, nilai ekonomi karang sebagai nursery ground memiliki nilai yang paling kecil. Hal ini disebabkan karena tutupan karang hidup yang tidak terlalu luas. Berdasarkan rincian perhitungan ekonomi tersebut di atas, maka didapatkan total nilai ekonomi pada ekosistem terumbu karang dan mangrove di daerah penelitian adalah sebesar 172,5 milyar rupiah per-tahun, dimana 141,4 milyar rupiah per-tahun dihasilkan oleh terumbu karang dan 31,1 milyar rupiah per-tahun oleh mangrove. Perhitungan tersebut berdasarkan pada waktu pengambilan data citra dan asumsi nilai ekonomi yang berlaku pada referensi yang digunakan. Nilai tersebut dapat berubah sesuai dengan tingkat kenaikan harga atau inflasi yang berlaku.

Tabel 3. potensi ekonomi ekosistem terumbu karang dan mangrove

Table 3. economic potencies of coral reef and mangrove ecosystems

\begin{tabular}{|c|c|c|c|}
\hline Code* & Calculation & $\begin{array}{l}\text { The economic value (per } \\
\text { component) }\end{array}$ & $\begin{array}{l}\text { The total of economic value } \\
\text { (per ecosystem) }\end{array}$ \\
\hline TK.1 & $53.63 \%$ x 55.73 ha $\times \mathrm{Rp} 30,000,000$ & Rp 896,639,970/year & \multirow[t]{4}{*}{ Rp 141,349,923,270/year } \\
\hline TK.2 & $10,908.59 \mathrm{~m} \times 2.5 \mathrm{~m} \times \mathrm{Rp} 3,600,000$ & $\mathrm{Rp} 98,177,310,000$ & \\
\hline TK.3 & $\begin{array}{l}\text { 2,336 individual /ha } x 838.31 \text { ha } x \\
\operatorname{Rp} 20,000\end{array}$ & Rp 39,165,843,200 & \\
\hline TK.4 & $\begin{array}{l}\text { Species of Holothuria coluber } \\
125 \text { individual /ha x } 838.31 \text { ha } \times \mathrm{Rp} \\
10,000=\mathrm{Rp} 1,047,887,500 \\
\text { Species of Actinophyga lecanora } \\
41 \text { individual /ha } \times 838.31 \text { ha } \times \mathrm{Rp} \\
60,000=\mathrm{Rp} 2,062,242,600\end{array}$ & $\operatorname{Rp} 3,110,130,100$ & \\
\hline M.1 & 63.64 ha x Rp 30,000,000 & Rp 1,900,200,000/year & \multirow[t]{2}{*}{ Rp. 31,108,350,000/year } \\
\hline M.2 & $3,245.35 \mathrm{~m} \times 2.5 \mathrm{~m} \times \mathrm{Rp} 3,600,000$ & Rp 29,208,150,000 & \\
\hline
\end{tabular}

The total economic value of study area

Rp. 172,458,273,270/year

*) the code of parameters refers to Table 1 .

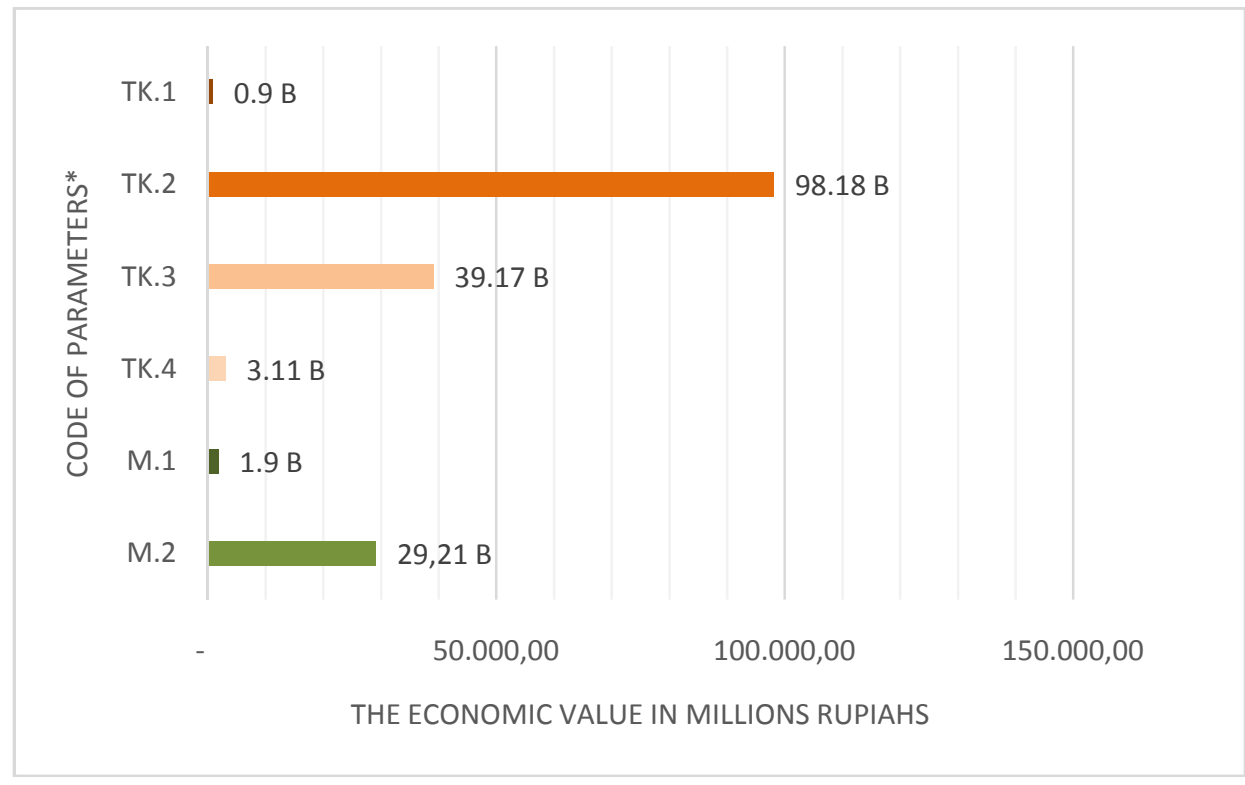

*) the code of parameters refers to Table 1 .

Gambar 5. Nilai ekonomi terumbu karang dan mangrove di Desa Teluk Limau

Figure 5. The economic value of coral reef and mangrove in Teluk Limau village 


\section{Pembahasan}

Habitat pada ekosistem terumbu karang dan mangrove di daerah penelitian berhasil dipetakan menggunakan data citra satelit Landsat 8 OLI dengan akurasi tematik yang cukup baik. Akurasi tersebut sudah mencukupi jika dibandingkan dengan penelitian lain dengan kisaran akurasi 30\% hingga 90\% (Goodman et al., 2013). Prayudha (2012) dalam penelitiannya mengenai pemetaan sumberdaya pesisir di Ternate mendapatkan akurasi yang tidak jauh berbeda dengan data satelit serupa yaitu sebesar $71,08 \%$. Mumby et al. (1998) dengan citra satelit yang serupa yaitu Landsat-7 ETM+ bahkan mampu memaksimalkan akurasi hingga sebesar $73 \%$. Meskipun akurasi yang dihasilkan pada penelitian ini sudah cukup baik, tetapi objek dengan ukuran kurang dari 15 x 15 meter persegi tidak dapat di identifikasi karena keterbatasan resolusi spasial citra. Oleh karena itu, tidak menutup kemungkinan adanya beberapa objek yang tidak dapat terpetakan. Potensi penggunaan data resolusi spasial yang lebih tinggi dapat meningkatkan akurasi hingga 90\% (Goodman et al., 2013). Sebagai contoh, Mumby et al. (1998) dalam penelitiannya menggunakan CASI mampu menghasilkan akurasi hingga 89\%. Kekurangan dari data satelit resolusi tinggi secara khusus di Indonesia adalah masih kurangnya akses untuk mendapatkan data tersebut, karena cukup mahal dan hanya disediakan oleh beberapa institusi tertentu. Keterbatasan penggunaan data citra satelit lainnya adalah kondisi atmosfer sangat mempengaruhi ketersediaan datanya. Indonesia berada di wilayah tropis dengan kondisi tutupan awan yang cukup banyak, sehingga menyulitkan untuk mendapatkan data citra satelit dengan liputan yang baik. Analisis citra satelit yang digunakan pada contoh penilaian ekonomi pesisir ini hanya dilakukan pada satu waktu saja, sehingga bersifat statis. Pendekatan dinamis atau multitemporal pada penilaian ekonomi akan lebih lebih baik dilakukan, karena dapat menyajikan gambaran pada masa lampau dan yang akan datang. Hal tersebut sangat bermanfaat bagi penentu kebijakan untuk melihat dampak perubahan ekosistem dan pengaruhnya terhadap nilai ekonomi yang dihasilkan dari kebijakan dalam pengelolaan wilayah atau ekosistem tersebut (Nemec \& Raudsepp-Hearne, 2012).

Data luasan dan panjang garis pantai yang diperoleh dari hasil penelitian ini dapat digunakan untuk menghitung valuasi ekonomi terumbu karang dan mangrove. Total potensi ekonomi dari ekosistem terumbu karang dan mangrove pada kajian ini adalah sebesar Rp. 172.458.273.270,per-tahun. Berdasarkan hasil pada daerah kajian, potensi ekonomi yang tinggi terdapat pada ekosistem terumbu karang yaitu $\mathrm{Rp}$ 141.349.923.270,- per-tahun, dikarenakan luasannya yang lebih besar dibandingkan dengan mangrove (Rp. 31.108.350.000,- per-tahun). Fungsi ekologi kedua ekosistem baik terumbu karang maupun mangrove sebagai pelindung garis pantai memiliki nilai yang relatif tinggi. Fungsi ekologi tersebut tergolong sebagai potensi ekonomi yang memiliki dampak tidak langsung, dimana dampaknya dirasakan dalam jangka waktu yang panjang. Nilai ekonomi terumbu karang sebagai pelindung garis pantai pada kajian wilayah lain dengan panjang garis pantai yang hampir sama yaitu di Banda Neira menghasilkan nilai yang lebih kecil dibandingkan hasil yang didapatkan pada penelitian ini (Mira et al, 2017). Hal ini disebabkan karena asumsi dasar biaya pembuatan tanggul pelindung pantai yang sangat berbeda pada tiap lokasi.

Pada ekosistem terumbu karang, nilai potensi ekonomi karang sebagai nursery ground cukup kecil dibandingkan dengan fungsi lainnya. Hal ini disebabkan karena luas tutupan karang hidup yang cukup kecil. Melalui peta sebaran habitat bentik (Gambar 4), pasir atau dapat disebut subtrat keras terbuka (bare subtratum) mendominasi tutupan didasar perairan di pesisir pantai Desa Teluk Limau. Sementara itu tutupan yang paling sedikit adalah karang dengan komunitas berdasarkan pengamatan lapangan bervariasi yang terdiri dari karang hidup dan karang mati baik yang tertutup alga maupun tidak. Melalui peta habitat bentik yang dihasilkan serta pengamatan langsung dilapangan juga diketahui bahwa tutupan makroalga memiliki luasan yang cukup besar dan mengelilingi kelompok-kelompok karang yang tumbuh pada area rataan karang (reef flat). Keberadaan makroalga yang tinggi disekitar karang dapat menyebabkan semakin kecilnya luasan karang hidup kedepannya karena terjadinya kompetisi tempat hidup dan hal tersebut kemungkinan juga dapat berdampak pada nilai ekonomi karang. Perlu kajian lebih lanjut untuk mengkonfirmasi kemungkinan tersebut.

Tutupan padang lamun (seagrass) tidak ditemukan pada lokasi penelitian baik dari hasil pengolahan citra maupun pengamatan langsung di lapangan. Oleh sebab itu nilai ekonominya sebagai nursery ground, filtrasi, pelindung pantai dan penyerap karbon tidak dapat dihitung (Hafizt, 2013; Hutomo and Nontji 2014; Kennedy and 
Björk 2009). Sementara itu tutupan mangrove dapat di interpretasi pada citra walaupun luasannya termasuk kecil. Luasan mangrove yang telah dihitung melalui citra penginderaan jauh belum mewakili luas mangrove seluruhnya di lapangan. Hal tersebut dikarenakan citra satelit yang digunakan memiliki resolusi spasial saluran pankromatik sebesar 15 meter, sehingga luasan mangrove yang kurang dari luas piksel tersebut tidak dapat diidentifikasi melalui citra satelit. Hal tersebut menjadi keterbatasan metode penggunakan citra resolusi menengah (LANDSAT) untuk perhitungan valuasi ekonomi pada kajian ini. Sehingga untuk perhitungan lebih detail dibutuhkan citra dengan resolusi spasial yang lebih tinggi seperti Sentinel (ESA, 2015), Worldview (digital globe, 2009), atau Planet (Marshall et al., 2017).

Total potensi ekonomi pada kedua ekosistem di Desa Teluk Limau tersebut belum mewakili total seluruh potensi ekonomi yang ada di lingkungan pesisir. Hal tersebut dikarenakan keterbatasan data lapangan khususnya yang berhubungan dengan biota lainnya yang bernilai ekonomis. Penilaian potensi sumberdaya alam terumbu karang dan mangrove pada penelitian ini hanya dilihat dari fungsi ekologisnya, baik yang memiliki nilai langsung seperti potensi ikan dan teripang maupun yang bernilai tidak langsung sebagai nursery ground dan pelindung garis pantai pada masing-masing ekosistem (Gambar 2).

Nilai kerugian akibat kerusakan pada kedua ekosistem tersebut tidak dihitung karena tidak mengkaji dampak kegiatan yang ada pada saat sekarang. Oleh karena itu dibutuhkan analisis lebih jauh untuk mengetahui distribusi dan luasan masing-masing ekosistem yang mengalami kerusakan dengan menggunakan citra multi temporal. Meskipun demikian, beberapa penelitian mengenai penilaian ekonomi pesisir dengan memanfaatkan informasi spasial (misal luas dan panjang) jarang menyajikan akurasi peta yang dihasilkan. Berbeda halnya dengan penelitian ini yang menyajikan informasi akurasi yang dihasilkan dari data citra satelit sebagai validasi data spasial yang dihasilkan, sehingga dapat mempengaruhi keakuratan penilaian ekonomi berdasarkan parameter spasial.

\section{Kesimpulan}

Berdasarkan penelitian yang dilakukan, citra LANDSAT 8 dapat digunakan untuk memetakan habitat perairan dangkal dan mangrove di wilayah penelitian dengan akurasi sebesar $71,05 \%$. Habitat perairan dangkal pada terumbu karang di wilayah penelitian yang berhasil dipetakan terdiri dari karang, makroalga, dan substrat terbuka. Informasi spasial yang dihasilkan melalui data citra satelit tersebut berupa luasan dan panjang memiliki batasan kedetilan dan akurasi yang dapat mempengaruhi perhitungan potensi ekonomi. Oleh karena itu, penggunaan citra satelit dengan resolusi yang lebih tinggi berpotensi untuk menghasilkan estimasi nilai ekonomi ekosistem pesisir yang lebih rinci dan presisi. Perhitungan potensi ekonomi terumbu karang dan mangrove dengan memanfaatkan informasi yang diperoleh dari pengolahan citra satelit dapat dilakukan lebih cepat, dimana potensi ekonomi kedua ekosistem tersebut sekitar 141,4 milyar rupiah per-tahun untuk terumbu karang dan 31,1 milyar rupiah per-tahun untuk ekosistem mangrove dan total potensi ekonomi kedua ekosistem tersebut sekitar 172,5 milyar rupiah per-tahun.

\section{Persantunan}

Ucapan terimakasih ditujukan kepada Prof. Wahyu S. Hantoro dan Prof. Pramudji atas kesempatan dan bantuan yang diberikan dalam melakukan pengambilan data pada penelitian ini. Terima kasih juga diberikan kepada Bapak Rikoh M. Siringoringo dan Bapak Kunto Wibowo yang telah mengijinkan penulis untuk menggunakan sebagian datanya untuk penelitian ini.

\section{Daftar Pustaka}

Astuti, J., Nurdin, M., \& Munir, A. (2008). Valuasi ekonomi sumberdaya alam dan lingkungan pesisir Kota Bontang Kalimantan Timur. Jurnal Analisis, 5(1), 53-64.

Badan Informasi Geospasial. (2014). Peraturan Kepala Badan Informasi Geospasial: Pedoman Teknis Pengumpulan dan Pengolahan Data Geospasial Habitat Dasar Perairan Laut Dangkal. Cibinong, Indonesia

Chavez, P. S. JR. (1988). An Improved DarkObject Substraction Technique for Atmospheric Scattering Correction of Multispectral Data. Remote Sensing of Environment, 24, 459-479.

Dahuri, R., Rais, J., Putra S., \& Sitepu M. (1996). Pengelolaan Sumber Daya Wilayah Pesisir dan Lautan Secara Terpadu. Jakarta, Indonesia: Pradnya Paramita.

Danoedoro, P. (2012). Pengantar Penginderaan Jauh Digital. Yogyakarta, Indonesia: Andi Offset. 
Digitalglobe. (2009). World View- 2 Design and Specifications. Westminster, CO: Author.

ESA. (2015). SENTINEL-2 User Handbook. Paris, France: Author.

Giyanto, Abrar, M., Tri Hadi, A., Budiyanto, A., Hafizt, M., Salatalohy, A., \& Iswari, M.Y. (2017). Status Terumbu Karang Indonesia 2017. Jakarta, Indonesia: Pusat Penelitian Oseanografi, Lembaga Ilmu Pengetahuan Indonesia.

Giyanto, Manuputty, A., Abrar, M., Siringoringo, R., Suharti, S., Wibowo, K., Edrus, I., Arbi, A., Cappenberg, H., Sihaloho, H., Tuti, Y., \& Zulfianita, D. (2014). Panduan Monitoring Kesehatan Terumbu Karang. Jakarta, Indonesia: Coral Reef Rehabilitation and Management Project, Lembaga Ilmu Pengetahuan Indonesia.

Goodman, J., Purkis, S., \& Phinn, S. (2013). Coral Reef Remote Sensing. London, United Kingdom: Springer.

Green, E., Mumby, P., Edwards, A., \& Clark, C. (2000). Remote Sensing Handbook for Tropical Coastal Management. Paris, France: The United Nations Educational, Scientific and Cultural Organization.

Hafizt, M. (2013). Kajian Estimasi Standing Carbon Stock Padang Lamun Menggunakan Citra Quickbird di P. Kemujan, Kepulauan Karimunjawa (Master's thesis). Pascasarjana, Gadjah Mada University, Yogyakarta, Indonesia.

Hafizt, M., \& Danoedoro, P. (2015). Kajian Pengaruh Koreksi Kolom Air pada Citra Multispektral Worldview-2 untuk Pemetaan Habitat Bentik di Pulau Kemujan Kep. Karimunjawa Kabupaten Jepara. In C. Ita, M. Setyardi P, S. Ahmad, Y. Dipo, \& Y. Fajar (Eds), MAPIN. Prosiding Pertemuan Ilmiah Tahunan XX 2015 (pp. 566 - 575). Bogor, Indonesia.

Hafizt, M., Iswari, M. Y., \& Prayudha, B. (2017a). Assessment of LANDSAT-8 classification method for benthic habitat mapping in Padaido Islands, Papua. Oseanologi dan Limnologi di Indonesia, 2(1), 1-13.

Hafizt, M., Manessa, M. D. M., Adi, N. S., \& Prayudha, B. (2017b). Benthic Habitat Mapping by Combining Lyzenga's Optical Model and Relative Water Depth Model in Lintea Island, Southeast Sulawesi. IOP Conference Series: Earth and Environmental Science, Vol. 98, 012037, DOI: 10.1088/1755-1315/98/1/012037.

Proceedings of The 5th Geoinformation
Science Symposium 2017 (GSS 2017) $27-$ 28 September 2017, Yogyakarta, Indonesia.Retrieved from https://iopscience.iop.org/article/10.1088/17 55-1315/98/1/012037/pdf.

Hermalena, L. (2016). Valuasi Ekonomi Kawasan Konservasi Nasional Laut Banda, Provinsi Maluku.Maritim, Sains, dan Teknologi Terapan 2018. Proceedings of Seminar Nasional MASTER 2016Kementrian Riset, Teknologi, dan Pendidikan Tinggi Politeknik Perkapalan Negeri Surabaya(pp. 5-13). Surabaya, Indonesia.

Hill, J., \& Wilkinson, C.. (2004). Methods for ecological monitoring of coral reefs. Townsville, Australia: Australian Institute of Marine Science.

Hutomo, M., \& Nontji, A. (2014). Panduan Monitoring Padang Lamun. Jakarta, Indonesia: PT Sarana Komunikasi Utama.

Jensen, J. (2007). Remote Sensing of The Environment: an Earth Resource Perspective, 2nd edition. Upper Saddle River, NJ: Pearson Prentice Hall.

Kamal, M., Phinn, S., Johansen K., Giri C., \& Thenkabail, P. S. (2015). Object-based approach for multi-scale mangrove composition mapping using multi-resolution image datasets. Remote Sens, 7, 4753-4783.

Kementerian PUPR. (2016). Permen PUPR Nomor 28/PRT/M/2016 tentang Pedoman Analisis Harga Satuan Pekerjaan Bidang Pekerjaan Umum. Jakarta, Indonesia: Author.

Kennedy, H., \& Björk M. (2009). The management of natural coastal carbon sinks: IUCN Report. Sheffield, United Kingdom: Natural England.

Lillesand, T. M., Kiefer, R. W., \& Chipman J. W. (2004). Remote Sensing and Image Interpretation. 5th ed. Hoboken, NJ: John Wiley \& Sons.

Long, B. G., \& Skewes T. D. (1996). A technique for mapping mangroves with LANDSAT TM satellite data and geographic information system. Estuarine, Coastal and Shelf Science, 43(3), 373-381.

LSDS-1574 V1. 2015. LANDSAT 8 (L8) Data Users Handbook. Sioux Falls, SD: Department of the Interior U.S. Geological Survey.

Maharmingnastiti, W., Saputra S. W., \& Wijayanto, D. (2015). Valuasi ekonomi ekosistem terumbu karang di perairan Karang Kelop Kabupaten Kendal. Dipo- 
negoro Journal of Maquares,4, 188-194.

Marshall, W., Schingler, R., Govindhasamy, K., Oppenheimer, D., Wild, A., Wolverton, S., Allamano, C. B., Malinasky, L., \& Campitelli, T. (2017). Planet. Retrieved from https://www.planet.com/.

Mira, S., Saptanto, \& Hikmah. (2017). Valuasi nilai ekonomi terumbu karang di Banda Neira. Jurnal Sosek Kelautan dan Perikanan, 12(1), 11-20.

Mumby, P.J., Clark, C. D., Green, E. P., \&Edwards, A. J. (1998). Benefits of water column correction and contextual editing for mapping coral reefs. International Journal of Remote Sensing, 19(1), 203-210.

Noviyanti, R, \& Rusdiyanto E. (2009). Valuasi Ekonomi Sumberdaya Pesisir Dan Laut Di Wilayah Teluk Banten Kabupaten Serang. Proceedings of Seminar Nasional Universitas Budi Luhur, 14 Agustus 2009, Jakarta, Indonesia. Retrieved from http:// repository.ut.ac.id/7413.

Prayudha, B. (2012). Pemetaan Sumberdaya Kepesisiran Melalui Teknologi Penginderaan Jauh di Kota Ternate. Ekosistem Pesisir Ternate, Tidore, dan Sekitarnya (pp. 7 - 18). Jakarta, Indonesia: Pusat Penelitian Oseanografi, Lembaga Ilmu Pengetahuan Indonesia.

Prayudha, B. (2014). Pemetaan Habitat Dasar
Perairan Laut Dangkal. Jakarta, Indonesia: Coral Reef Rehabilitation and Management Project, Lembaga Ilmu Pengetahuan Indonesia.

Pusat Data Statistik dan Informasi KKP. (2015). Kelautan dan Perikanan Dalam angka Tahun 2015. R. R. Damanti \& M. Nirmalanti (Eds). Jakarta, Indonesia: Kementerian Kelautan dan Perikanan.

Suharti, S. R. (n.d.). Metodologi Penelitian Ikan Karang.Jakarta, Indonesia: Pusat Penelitian Oseanografi, Lembaga Ilmu Pengetahuan Indonesia.

Suparmoko, M., Ratnaningsih, M., Setyarko, Y., \& Widyantara, G. (2003). Valuasi ekonomi sumberdaya alam laut dan pesisir Pulau Kangean. Prosiding Seminar Nasional III dan Kongres I NRE. Proceedings ofSeminar Nasional I Neraca Sumberdaya Alam dan Limgkungan, Kongres IOrganisasi Profesi Praktisi Neraca Sumberdaya Alam dan Lingkungan Indonesia (pp. 1-21). Purwokerto, Indonesia.

Suyarso, Ulumuddin, Y. I., \& Prayuda, B. (2011). Mapping of coral reef ecosystem in the Natuna. Journal of Coastal Development, 15(1), 24-33.

UU 27. (2007). Undang Undang Pengelolaan Wilayah Pesisir dan Pulau-Pulau Kecil. 